\title{
Pengaruh Komitmen Organisasi, Locus Of Control dan Implementasi Good Governance terhadap Kecenderungan Kecurangan (Fraud) Akuntansi pada Lembaga Perkreditan Desa di Kecamatan Seririt
}

\author{
Komang Rosa Lyana ${ }^{1 *}$,Edy Sujana ${ }^{2}$ iD \\ ${ }^{12}$ Jurusan Ekonomi dan Akuntansi, Universitas Pendidikan Ganesha, Singaraja, Bali, Indonesia \\ *rosaliana1998@gmail.com ${ }^{1 *}$
}

\begin{abstract}
Abstrak
Penelitian ini bertujuan untuk mengetahui pengaruh komitmen organisasi, locus of control dan implementasi good governance terhadap kecenderungan kecurangan (Fraud) akuntansi pada lembaga perkreditan desa di Kecamatan Seririt. Populasi yang digunakan oleh peneliti dalam penelitian ini adalah seluruh LPD di Kecamatan Seririt yang berjumlah 25 LPD. Teknik sampel yang digunakan yaitu purposive sampling. Jumlah sampel dalam penelitian ini yaitu 21 LPD dengan total responden sebanyak 63 responden. Teknik analisis data dalam penelitian ini adalah kuantitatif dengan menggunakan analisis regresi linier berganda dengan bantuan program SPSS versi 24.0 for windows. Hasil dari penelitian menunjukkan bahwa (1) komitmen organisasi berpengaruh negatif dan signifikan terhadap kecenderungan kecurangan (fraud) akuntansi pada LPD di Kecamatan Seririt, (2) locus of control berpengaruh positif dan signifikan terhadap terhadap kecenderungan kecurangan (fraud) akuntansi pada LPD di Kecamatan Seririt, (3) implementasi good governance berpengaruh negatif dan signifikan terhadap terhadap kecenderungan kecurangan (fraud) akuntansi pada LPD di Kecamatan Seririt.
\end{abstract}

Kata Kunci : Komitmen Organisasi, Locus Of Control, Implementasi Good Governance, kecenderungan kecurangan (Fraud) akuntansi

\section{Abstract}

This study aims to determine the effect of organizational commitment, locus of control and implementation of good governance on the tendency of accounting fraud in village credit institutions in Seririt District. The population used by researchers in this study were all LPD in Seririt District, totaling 25 LPD. The sampling technique used is purposive sampling. The number of samples in this study were 21 LPD with a total of 63 respondents. The data analysis technique in this study is quantitative using multiple linear regression analysis with the help of SPSS version 24.0 for windows. The results of the study show that (1) organizational commitment has a negative and significant effect on the tendency of accounting fraud at LPD in Seririt District, (2) locus of control has a positive and significant effect on the tendency of accounting fraud in LPDs in Seririt District, (3) the implementation of good governance has a negative and significant effect on the tendency of accounting fraud at the LPD in Seririt District.

Keywords: Organizational Commitment, Locus Of Control, Good Governance Implementation,Accounting Fraud Tendency

\section{Pendahuluan}

Kecenderungan kecurangan akuntansi atau yang dalam bahasa pengauditan disebut dengan fraud, saat ini menjadi berita utama dalam pemberitaan media yang sering terjadi. Menurut Adinda (2015) fraud merupakan penipuan yang sengaja dilakukan untuk menimbulkan kerugian pihak lain dan memberikan keuntungan bagi pelaku kecurangan. Organisasi yang memiliki peluang paling besar terjadinya kecurangan (fraud) adalah organisasi yang bergerak dibidang keuangan atau di lembaga keuangan.

$\begin{array}{ll}\text { History: } & \text { Publisher: Undiksha Press } \\ \text { Received: August } 2021 & \text { Licensed: This work is licensed under } \\ \text { Revised: Oktober } 2021 & \text { a Creative Commons Attribution 3.0 License } \\ \text { Accepted: November } 2021 & \\ \text { Published: November } 2021 & \end{array}$


Akuntansi pada Lembaga Perkreditan Desa di Kecamatan Seririt

Lembaga jasa keuangan mempunyai peranan penting dalam menggerakkan roda perekonomian suatu negara. Hal ini terjadi karena transaksi keuangan biasanya lebih dominan terjadi di lembaga keuangan perbankan atau lembaga keuangan non perbankan baik yang berada ditingkat kabupaten ataupun yang berapa ditingkat pedesaan. Salah satu lembaga keuangan yang berada di tingkat pedesaan, khususnya di provinsi Bali adalah lembaga keuangan yang bernama Lembaga Perkreditan Desa (LPD).

Tujuan pendirian sebuah LPD pada setiap desa adat, berdasarkan penjelasan Peraturan Daerah No. 8/tahun 2002 yaitu mendukung pembangunan ekonomi pedesaan melalui peningkatan kebiasaan menabung masyarakat dan menyediakan kredit bagi usaha skala kecil, untuk menghapus bentuk-bentuk eksploitasi dalam kredit, untuk menciptakan kesempatan setara bagi kegiatan usaha pada tingkat desa dan untuk meningkatkan tingkat monoterisasi di daerah pedesaan.

LPD di Buleleng mengalami pertumbuhan yang cukup pesat yakni dengan terdapatnya 169 LPD yang tersebar di setiap wilayahnya. Dibalik pesatnya pertumbuhan dan perkembangan LPD di Kabupaten Buleleng, dibayangi juga oleh maraknya LPD yang bermasalah. Berdasarkan data yang diperoleh dari Sekretariat Daerah Pemkab Buleleng Bagian Perekonomian dan Pembangunan (Ekbang) sebanyak 20 dari 169 LPD di Kabupaten Buleleng dinyatakan macet pada triwulan I tahun 2021. Pada triwulan I tahun 2021, jumlah LPD macet di Kabupaten Buleleng yaitu sebanyak 20 LPD dengan rincian 4 LPD di Kecamatan Seririt, 3 LPD di Kecamatan Busungbiu, 6 LPD di Kecamatan Banjar, 1 LPD di Kecamatan Sukasada, 3 LPD di Kecamatan Buleleng, 1 LPD di Kecamatan Sawan, 2 LPD di Kecamatan Kubutambahan. Tidak dapat dipungkiri banyak LPD di Kabupaten Buleleng yang melakukan tindakan kecurangan (fraud). Salah satunya LPD yang berada di Kecamatan Seririt. Berdasarkan data yang diperoleh dari Sekretariat Daerah Pemkab Buleleng Bagian Perekonomian dan Pembangunan (Ekbang) sebanyak 4 dari 25 LPD di Kecamatan Seririt dinyatakan macet pada triwulan I tahun 2021.

Dari perbandingan jumlah desa/kelurahan dengan jumlah LPD di Seririt, dapat disimpulkan bahwa LPD di Seririt juga berkembang dengan baik. Namun dalam perkembangannya tidak lepas juga dari masalah yang menyebabkan LPD mengalami kerugian yang cukup material. Terbukti dari adanya beberapa kasus kecurangan yang pernah terjadi sebagai berikut: 1) Kasus penyelewengan dana di LPD Desa Unggahan Kecamatan Seririt pada tahun 2019 dengan total kerugian sebesar Rp. 200.000.000(Mustofa, 2020). 2) Kasus penyelewengan dana lembaga perkreditan desa (LPD) Kalianget oleh mantan ketua LPD Kalianget . Kecurangan ini sudah terjadi sepanjang tahun 2018 sampai tahun 2020 dengan total kerugian sebesar Rp. 355.000 .000 (Zakky, 2020). 3) Tindakan korupsi oleh ketua LPD Pengastulan pada tahun 2019 dengan total kerugian sebesar Rp. 160.000.000 (Suyatra, 2019). Dari hasil penyelidikan dan keterangan dari saksi bahwa modus tiga kasus ini hampir sama yaitu oknum tidak menyetorkan uang cicilan ataupun pelunasan kredit ke LPD dan digunakan untuk keperluan pribadi.

Motivasi seseorang dalam melakukan tindakan kecenderungan kecurangan akuntansi atau fraud relatif bermacam-macam. Salah satu teori yang menjelaskan tentang motivasi tersebut adalah fraud triangle theory. Teori inilah yang digunakan dalam penentuan variabel pada penelitian ini. Variabel yang digunakan merupakan proksi dari unsur-unsur fraud triangle, yang terdiri dari tekanan, kesempatan dan sikap/rasionalisasi. Tekanan yang dimaksud adalah tekanan dari pihak manajemen untuk melakukan kecurangan, kesempatan berarti terdapat situasi di dalam suatu instansi untuk melakukan kecurangan, dan sikap/rasionalisasi menunjukkan dimana suatu instansi merasionalisasikan tindakan yang tidak jujur atau berbuat curang (Karyono, 2013). 
Kecenderungan kecurangan dipengaruhi oleh ada atau tidaknya rasionalisasi atau pembenaran. Rasionalisasi (Rationalization) yaitu pertimbangan dari adanya sebuah kesenjangan integritas pribadi karyawan atau penalaran moral lainnya (Karyono, 2013). Pelaku fraud selalu berusaha untuk melegitimasi perbuatannya dengan berupaya untuk mencari-cari alasan. Hal ini dilakukan untuk menenangkan perasaan yang bersangkutan sehingga jika dilakukan tidak menimbulkan ketakutan dalam dirinya. Pada penelitian kali ini peneliti memproyeksikan rasionalisasi dengan komitmen organisasi.

Salah satu cara yang dapat digunakan untuk meminimalisir kecenderungan kecurangan (fraud) akuntansi yaitu dengan meningkatkan komitmen organisasi (Widiautami, 2017). Komitmen organisasi merupakan tingkat sampai sejauh mana seorang pegawai memihak pada suatu organisasi tertentu dan keterlibatan pegawai untuk mencapai tujuan organisasi, serta berniat untuk mempertahankan keanggotaannya dalam organisasi itu (Ikhsan dkk, 2011). Peneliti menggunakan variabel komitmen organisasi karena komitmen organisasi menunjukkan sejauh mana pegawai tersebut mengenal dan terikat pada sebuah organisasi yang akan menjadikan pegawai tersebut lebih mementingkan instansi tempatnya bekerja dari pada kepentingan pribadi dan berusaha menjadikan instansi lebih baik untuk mencapai tujuannya.

Penelitian yang dilakukan Widiautami (2017) memperoleh hasil yaitu komitmen organisasi berpengaruh negatif dan signifikan terhadap kecenderungan kecurangan (fraud) akuntansi, yang berarti komitmen organisasi yang tinggi dapat meminimalisir terjadinya kecenderungan kecurangan (fraud). Hal tersebut juga didukung oleh hasil penelitian dari Pratiwi (2019) dan Virmayani (2017) yang menyatakan bahwa komitmen organisasi berpengaruh negatif dan signifikan terhadap kecenderungan kecurangan (fraud) akuntansi. Memiliki komitmen yang tinggi terhadap instansi berarti pegawai juga memiliki dedikasi yang tinggi terhadap instansi. Berdasarkan penelitian-penelitian sebelumnya yang relevan, maka dapat dirumuskan hipotesis sebagai berikut:

$\mathrm{H}_{1}$ : Komitmen Organisasi berpengaruh negatif dan signifikan terhadap kecenderungan kecurangan (fraud) akuntansi.

Selain dari sisi rasionalisasi, kecenderungan kecurangan juga dipengaruhi oleh besar tidaknya tekanan. Tekanan (Pressure) adalah motivasi dari individu untuk bertindak curang yang disebabkan oleh adanya tekanan keuangan maupun non keuangan, serta dapat disebabkan pula oleh tekanan pribadi maupun tekanan dari organisasi. Pada penelitian kali ini peneliti memproyeksikan tekanan dengan adalah locus of control.

Locus of control merupakan cara pandang seseorang terhadap suatu peristiwa apakah dia dapat atau tidak dapat mengendalikan peristiwa yang terjadi padanya (Lestari, 2010). Locus of control dibedakan menjadi dua yaitu locus of control internal dan locus of control eksternal. Respati (2011) berpendapat bahwa seseorang dengan locus of control eksternal dirasakan kurang bertanggungjawab dengan hasil dari tindakannya dibandingkan seseorang dengan locus of control internal. Seseorang dengan locus of control internal yang tinggi lebih mengenali secara langsung hubungan antara perilaku dan hasil dari tindakannya. Akibatnya, seseorang dengan locus of control internal lebih bertanggung jawab dengan hasil dari tindakan atau perilakunya terhadap diri mereka sendiri dan menentukan sendiri mengenai apa yang benar dan salah untuk pedoman perilaku. Oleh karena itu, seseorang dengan locus of control internal lebih tidak berpeluang melakukan tindakan kecurangan (fraud). Sebaliknya, seseorang dengan locus of control eksternal lebih bertanggung jawab dengan pihak-pihak lain dan faktor-faktor situasional, oleh karena itu mereka lebih berpeluang melakukan tindakan kecurangan (fraud). 
Akuntansi pada Lembaga Perkreditan Desa di Kecamatan Seririt

Berdasarkan penelitian yang dilakukan oleh Wirakusuma (2019) menyatakan bahwa locus of control berpengaruh positif dan signifikan terhadap kecenderungan kecurangan akuntansi. Hal tersebut juga didukung oleh hasil penelitian dari Rahayu (2018) bahwa locus of control berpengaruh positif dan signifikan terhadap kecenderungan kecurangan akuntansi. Penelitian Budiyanti (2020) juga menyatakan bahwa locus of control berpengaruh positif dan signifikan terhadap kecenderungan kecurangan (fraud) akuntansi. Berdasarkan uraian tersebut, maka disusun hipotesis berikut:

$\mathrm{H}_{2}$ : Locus of control berpengaruh positif dan signifikan terhadap kecenderungan kecurangan (fraud) akuntansi.

Selain dari sisi rasionalisasi dan tekanan kecenderungan kecurangan juga dipengaruhi oleh besar tidaknya kesempatan atau peluang. Peluang yang besar membuat kecenderungan kecurangan lebih sering terjadi. Untuk menangani masalah tersebut, diperlukan monitoring dalam sebuah instansi dan untuk mendapatkan hasil monitoring yang baik, maka diperlukan penerapan prinsip good governance (Tunggal, 2010).

Faktor lain sebagai pemicu terjadinya kecenderungan kecurangan akuntansi adalah lemahnya penerapan prinsip-prinsip good governance dalam suatu organisasi (Tunggal, 2010). Menurut FCGI, Good Governance merupakan suatu peraturan mengenai hubungan antar pemangku kepentingan seperti pemerintah, karyawan maupun pihak intern dan ekstern yang bersangkutan atau suatu sistem yang digunakan untuk mengendalikan instansi atau perusahaan (Saftarini, 2015). Menurut Peraturan Pemerintah No. 101 Tahun 2000, Good Governance merupakan kepemerintahan

yang mengembangkan dan menerapkan prinsip- prinsip profesionalitas, akuntabilitas, transparansi, pelayanan prima, demokrasi, efisiensi, efektivitas, supremasi hukum dan dapat diterima oleh seluruh masyarakat. Selain itu good governance juga digunakan sebagai panduan untuk meningkatkan efektivitas dan efisiensi dalam pemakaian sumber daya organisasi dengan mengatur pola hubungan antara pemerintah, dunia usaha swasta, dan masyarakat sehingga terjadi penyelenggaraan pemerintah yang bersih, demokratis dan efektif sesuai dengan cita-cita terbentuknya masyarakat yang makmur (Badewin, 2018). Oleh karena itu, penerapan good governance yang optimal akan mencegah adanya peluang untuk melakukan tindakan kecurangan.

Hasil penelitian yang dilakukan oleh Sari (2015), mengatakan bahwa implementasi good governance berpengaruh negatif signifikan terhadap kecenderungan kecurangan (fraud). Hal tersebut juga didukung oleh hasil penelitian dari Pratiwi (2019) dan Saftarini (2015) yang menyatakan bahwa implementasi good governance berpengaruh negatif dan signifikan terhadap kecenderungan kecurangan (fraud) akuntansi. Berdasarkan uraian tersebut, maka disusun hipotesis berikut:

$\mathrm{H}_{3}$ : Implementasi Good Governance berpengaruh negatif dan signifikan terhadap kecenderungan kecurangan (fraud) akuntansi.

Penelitian ini merupakan pengembangan penelitian yang dilakukan oleh (Suarniti dan Maria, 2019). Perbedaan penelitian ini dengan penelitian terdahulu terletak pada variabel bebas dan lokasi penelitian. Perbedaan pada variable bebas yaitu dengan menambahkan variabel baru seperti locus of control dan implementasi good governance dan menghilangkan dua variabel yaitu pengaruh moralitas individu dan kesesuaian kompensasi. Penggunaan variabel locus of control dan implementasi good governance sebagai variabel baru karena terjadi ketidakonsistenan pada hasil penelitian terdahulu sehingga peneliti ingin menguji kembali variabel ini. Perbedaan kedua pada penelitian ini yaitu terletak pada lokasi penelitian. 
Adapun tujuan dari penelitian ini yaitu (1) untuk mengetahui pengaruh komitmen organisasi terhadap kecenderungan kecurangan (fraud) akuntansi pada LPD di Kecamatan Seririt, (2) untuk mengetahui pengaruh locus of control terhadap kecenderungan kecurangan (fraud) akuntansi pada LPD di Kecamatan Seririt, (3) untuk mengetahui pengaruh implementasi good governance terhadap kecenderungan kecurangan (fraud) akuntansi pada LPD di Kecamatan Seririt.

\section{Metode}

Rancangan penelitian yang digunakan dalam penelitian ini adalah penelitian dengan metode kuantitatif. Variabel yang digunakan dalam penelitian ini yaitu komitmen organisasi, locus of control dan implementasi good governance terhadap kecenderungan kecurangan (Fraud) akuntansi pada lembaga perkreditan desa di Kecamatan Seririt. Populasi yang digunakan peneliti dalam penelitian ini adalah seluruh LPD di Kecamatan Seririt yang berjumlah 25 LPD dan dengan total pegawai LPD sebanyak 84 orang. Teknik sampel yang digunakna yaitu purposive sampling. Sampel dalam penelitian ini adalah LPD di Kecamatan Seririt, Kabupaten Buleleng yang memenuhi kriteria sampel sebagai berikut: 1)Seluruh LPD di Kecamatan Seririt yang terdaftar di LPLPD Kabupaten Buleleng. 2) LPD yang masih aktif beroperasi. 3) Responden yang dipilih adalah pihak-pihak yang memiliki potensi atau yang terlibat dalam proses pengelolaan keuangan dan pelaporan keuangan LPD yaitu pemucuk (ketua), petengen (kasir), dan kasinoman (tata usaha). Dari kriteria tersebut maka diperolah sampel sebanyak 63 orang.

Adapun jenis data yang digunakan dalam penelitian ini adalah data primer dan sekunder. Data primer dalam penelitian ini berupa skor jawaban yang diperoleh dari pengisian kuesioner mengenai komitmen organisasi, locus of control, implementasi good governace dan kecenderungan kecurangan akuntansi.

Data sekunder didapat melalui media perantara, didapatkan data sekunder berupa nama-nama LPD di Kecamatan Seririt dan data kesehatan LPD di Kecamatan Seririt. Kuesioner digunakan sebagai metode dalam mengumpulkan data yang disebarkan pada responden terpilih. Data dikumpulkan dengan membagikan instrumen penelitian berupa kuesioner yang diberikan kepada responden terpilih. Setiap instrumen disusun dari beberapa butir pertanyaan atau pernyataan dimana responden akan memberikan penilaian setiap butir pertanyaan atau pernyataan dengan menggunakan skala Likert. Teknik analisis data yang digunakan dalam penelitian ini meliputi analisis statistik deskriptif, pengujian kualitas data berupa uji validitas dan reliabilitas, pengujian asumsi klasik berupa pengujian normalitas, multikolinieritas, dan heteroskedestisitas serta yang terakhir yakni pengujian hipotesis berupa analisis regresi berganda, uji koefisien determinasi dan uji t.

\section{Hasil dan Pembahasan}

Hasil pada penelitian ini meliputi hasil uji statistik deskriptif, uji kualitas data, uji asumsi klasik, dan uji hipotesis. Uji statistik deskriptif dilakukan untuk mengetahui nilai minimum, maksimun, mean dan standar deviasi. Hasil uji statistik deskriptif disajikan pada tabel 1 berikut: 
Pengaruh Komitmen Organisasi, Locus Of Control dan Implementasi Good Governance terhadap Kecenderungan Kecurangan (Fraud) Akuntansi pada Lembaga Perkreditan Desa di Kecamatan Seririt

Tabel 1. Hasil Analisis Deskriptif

\begin{tabular}{cccccc}
\hline Variabel & $\mathrm{N}$ & Minimum & Maksimum & Rata-rata & Standar Deviasi \\
\hline $\mathrm{X}_{1}$ & 63 & 18 & 30 & 25,29 & 2,31 \\
\hline $\mathrm{X}_{2}$ & 63 & 23 & 35 & 28,97 & 3,01 \\
\hline $\mathrm{X}_{3}$ & 63 & 22 & 30 & 26,59 & 2,08 \\
\hline $\mathrm{Y}$ & 63 & 22 & 36 & 28,29 & 3,41 \\
\hline
\end{tabular}

(Sumber: Output SPSS 24.0)

Berdasarkan hasil uji statistik deskriptif, dapat dilihat bahwa variabel Komitmen organisasi (X1) bernilai minimum 18, bernilai maksimum 30, serta rerata senilai 25,29 dengan standar deviasi (SD) senilai 2,31. Standar deviasi memiliki nilai di bawah rerata mengindikasikan penyebaran data komitmen organisasi dalam penelitian ini terdistribusi merata, artinya selisih data satu dengan data yang lainnya tidak terlalu tinggi. Data variabel locus of control (X2) bernilai minimum 23, bernilai maksimum 35, serta rerata senilai 28,97 dengan standar deviasi (SD) senilai 3,01. Standar deviasi memiliki nilai di bawah rerata mengindikasikan penyebaran data integritas dalam penelitian ini terdistribusi merata, artinya selisih data satu dengan data yang lainnya tidak terlalu tinggi. Data variabel implementasi good governance (X3) bernilai minimum 22, bernilai maksimum 30, serta rerata senilai 26,59 dengan standar deviasi (SD) senilai 2,08. Standar deviasi memiliki nilai di bawah rerata mengindikasikan penyebaran data implementasi good governance dalam penelitian ini terdistribusi merata, artinya selisih data satu dengan data yang lainnya tidak terlalu tinggi. Sementara itu, variabel kecenderungan kecurangan (fraud) akuntansi (Y) bernilai minimum 22, bernilai maksimum 36, serta rerata senilai 28,29 dengan standar deviasi (SD) senilai 3,41. Standar deviasi memiliki nilai di bawah rerata mengindikasikan penyebaran data kecenderungan kecurangan (fraud) akuntansi dalam penelitian ini terdistribusi merata, artinya selisih data satu dengan data yang lainnya tidak terlalu tinggi.

Uji kualitas data dilakukan untuk mengetahui apakah data yang sudah dikumpulkan melalui kuesioner bisa menunjukkan konsep pengujian secara tepat. Pengujian validitas serta reliabilitas termasuk dalam uji kualitas.Pengujian validitas serta reliabilitas termasuk dalam uji kualitas. Validitas diuji melalui hitungan keterkaitan antara nilai per butir pernyataan dengan keseluruhan nilai. Teknik korelasi Pearson's Correlation digunakan dalam pengujian validitas dengan bantuan program SPSS 24.0 for Windows. Menurut Gozali (2011), kriteria keputusan valid suatu pernyataan dinyatakan apabila nilai signifikansi (Sig.) $<\alpha=0,05$. Hasil setelah diuji menunjukkan bahwa nilai Sig. lebih kecil dari $\alpha=0,05$ maka seluruh butir pernyataan dikategorikan valid pada kuesioner komitmen organisasi (X1) locus of control (X2), implementasi good governance (X3) dan kecenderungan kecurangan (fraud) akuntansi $(\mathrm{Y})$.

Uji reliabilitas ditujukan untuk mengetahui konsistensi perolehan jawaban responden. Menurut (Ghozali, 2011), kriteria keputusan reliabel dinyatakan apabila Cronbach Alpha lebih dari 0,70. Setelah diuji, dapat dilihat adanya Cronbach Alpha diatas 0,70 pada semua variabel sehingga dikategorikan reliabel yang berarti adanya perolehan data atau jawaban yang konsisten pada tiap butir pernyataan sehingga adanya kemiripan antara perolehan jawaban dengan jawaban sebelumnya.

Apabila pengujian kualitas data telah terpenuhi, metode analisis data selanjutnya adalah uji asumsi klasik digunakan untuk mengetahui apakah data yang diperoleh dari responden melalui kuesioner dapat dianalisis menggunakan model regresi atau tidak. Uji normalitas dengan One Sample Kolmogorov-Smirnov Test, uji multikolinieritas, dan uji 
heteroskedastisitas masuk ke dalam pengujian asumsi klasik penelitian ini. Menurut (Ghozali, 2011), terdistribusinya data secara normal apabila Sig. mempunyai nilai di atas 0,05. Berdasarkan hasil uji normalitas yang telah dilakukan menunjukkan bahwa nilai Kolmogorov Smirnov sebesar 0,099 dengan nilai Sig. sebesar 0,200 sehingga dapat ditarik kesimpulan bahwa data-data diperoleh melalui kuesioner telah berdistribusi secara normal dan model penelitian ini memenuhi pengujian asumsi klasik normalitas.

Keberadaan hubungan antara satu variabel bebas (independen) dengan yang lainnya dapat diketahui melalui pengujian multikolinieritas. Besarnya Variance Inflation Factor (VIF) serta nilai tolerance menjadi tolak ukur terjadinya multikolinieritas atau tidak (Ghozali, 2011). Ketika VIF melebihi 10 atau tolerance bernilai di bawah 0,10 maka disanalah terjadi multikolinieritas. Hasil pengujian multikolinieritas menunjukkan bahwa setiap variabel independen bernilai VIF di bawah 10 serta tolerance yang melebihi 0,10 yang berarti antar variabel independen tidak terbentuknya gejala multikolinieritas.

Munculnya perbedaan varians satu residual dari satu pengamatan ke pengamatan lain dapat diketahui melalui pengujian heteroskedastisitas (Ghozali, 2011). Uji Glejser digunakan untuk mengetahui ada tidaknya heteroskedastisitas. Jika nilai signifikansi $>0,05$ maka terjadi homoskedastisitas, akan tetapi jika sebaliknya nilai signifikansi $<0,05$ maka terdapat heteroskedastisitas. Hasil pengujian heteroskedastisitas memperlihat adanya signifikansi melebihi 0,05 yang terbentuk antara variabel independen yang berarti tidak munculnya gejala heteroskedastisitas pada model regresi yang digunakan.

Analisis regresi linier berganda dipilih sebagai pengujian hipotesis yang ada sehingga permasalahan-permasalahan yang telah dirumuskan dapat dipecahkan untuk mengetahui adanya pengaruh pada dua variabel atau lebih. Setelah diuji melalui analisis konstanta dan koefisien beta, diperoleh persamaan garis regresi sebagai berikut:

Tabel 2. Hasil Analisis Linier Berganda

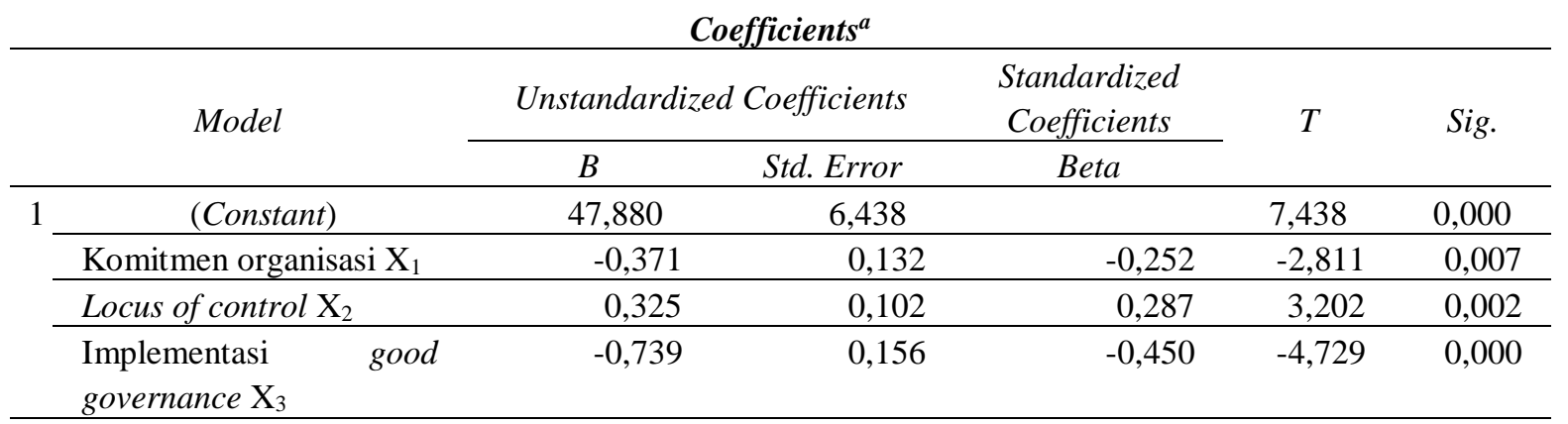

(Sumber: Output SPSS 24.0)

Berdasarkan tabel 2 maka didapat hasil persamaan regresi sebagai berikut.

$$
\begin{aligned}
& \mathrm{Y}=\alpha+\beta 1 \mathrm{X} 1+\beta 2 \mathrm{X} 2+\beta 3 \mathrm{X} 3+\beta 4 \mathrm{X} 4+\varepsilon \\
& \mathrm{Y}=47,880-0,371 \mathrm{X} 1+0,325 \mathrm{X} 2+-0,739 \mathrm{X} 3+\varepsilon
\end{aligned}
$$

Adapun hasil intrepretasi sebagai berikut (1) 47,880 menunjukan jika variabel komitmen organisasi (X1), locus of control (X2), dan implementasi good governance (X3) bernilai konstan, maka variabel kecenderungan kecurangan (fraud) akuntansi (Y) memiliki nilai positif 47,880 satuan, (2) Komitmen organisasi (X1) memiliki koefisien regresi -0,371. Nilai koefisien regresi yang negatif menunjukkan bahwa komitmen organisasi (X1) berpengaruh negatif terhadap kecenderungan kecurangan (fraud) akuntansi (Y). Hal ini menggambarkan bahwa setiap kenaikan 1 satuan komitmen organisasi (X1) dapat 
menurunkan kecenderungan kecurangan (fraud) akuntansi (Y) sebesar 0,371 dengan asumsi variabel independen yang lainnya tetap, (3) Locus of control (X2) memiliki koefisien regresi 0,325 . Nilai koefisien regresi yang positif menunjukkan bahwa locus of control (X2) berpengaruh positif terhadap kecenderungan kecurangan (fraud) akuntansi (Y). Hal ini menggambarkan bahwa setiap kenaikan 1 satuan locus of control (X2) dapat meningkatkan kecenderungan kecurangan (fraud) akuntansi (Y) sebesar 0,325 dengan asumsi variabel independen yang lainnya tetap, (4) Implementasi good governance (X3) memiliki koefisien regresi $-0,739$. Nilai koefisien regresi yang negatif menunjukkan bahwa implementasi good governance (X3) berpengaruh negatif terhadap kecenderungan kecurangan (fraud) akuntansi (Y). Hal ini menggambarkan bahwa setiap kenaikan 1 satuan implementasi good governance (X3) dapat menurunkan kecenderungan kecurangan (fraud) akuntansi (Y) sebesar 0,739 dengan asumsi variabel independen yang lainnya tetap.

Hasil analisis koefisien determinasi menunjukkan koefisien determinasi sebesar 0,736. Hal ini menunjukkan bahwa 73,6\% variabel kecenderungan kecurangan (fraud) akuntansi dipengaruhi oleh variabel komitmen organisasi, locus of control, dan implementasi good governance, sedangkan $26,4 \%$ dipengaruhi oleh faktor lain.

Berdasarkan hasil uji t pada tabel 2. menyatakan Hasil pengujian hipotesis pertama menunjukkan bahwa komitmen organisasi memiliki nilai signifikansi 0,007, dimana nilai tersebut lebih kecil dari 0,05 sehingga $\mathrm{H0}$ ditolak. Jadi, dapat disimpulkan bahwa komitmen organisasi berpengaruh negatif dan signifikan terhadap kecenderungan kecurangan (fraud) akuntansi. Hasil pengujian hipotesis kedua menunjukkan bahwa locus of control memiliki nilai signifikansi 0,002, dimana nilai tersebut lebih kecil dari 0,05 sehingga H0 ditolak. Jadi, dapat disimpulkan bahwa locus of control berpengaruh positif dan signifikan terhadap kecenderungan kecurangan (fraud) akuntansi. Hasil pengujian hipotesis ketiga menunjukkan bahwa implementasi good governance memiliki nilai signifikansi 0,000 , dimana nilai tersebut lebih kecil dari 0,05 sehingga H0 ditolak. Jadi, dapat disimpulkan bahwa implementasi good governance berpengaruh negatif dan signifikan terhadap kecenderungan kecurangan (fraud) akuntansi.

\section{Pengaruh Komitmen Organisasi Terhadap Kecenderungan Kecurangan (Fraud) Akuntansi}

Ditinjau dari hasil pengujian, komitmen organisasi berpengaruh negatif dan signifikan terhadap kecenderungan kecurangan (fraud) akuntansi pada LPD di Kecamatan Seririt. Hal ini dapat dilihat dari hasil analisis regresi linier berganda yang membuat variabel komitmen organisasi (X1) berkoefisien negatif $-0,371$ mengindikasikan timbulnya pengaruh negatif diantara variabel komitmen organisasi (X1) pada variabel kecenderungan kecurangan (fraud) akuntansi (Y). Signifikansi uji t variabel komitmen organisasi (X1) bernilai 0,007 yang berada di bawah 0,05 berarti variabel kecenderungan kecurangan (fraud) akuntansi (Y) dipengaruhi oleh variabel komitmen organisasi (X1) secara signifikan. Regresi linier berganda yang dianalisis serta uji $\mathrm{t}$ mengindikasikan peningkatan komitmen organisasi seorang pegawai LPD mengakibatkan penurunan tingkat fraud. Sebaliknya, apabila seorang pegawai LPD memiliki tingkat komitmen organisasi yang rendah maka kecenderungan untuk melakukan fraud akan semakin meningkat.

Ketika seorang pegawai memiliki komitmen yang tinggi terhadap LPD, maka pegawai tersebut akan berusaha dengan segala usaha dan upaya agar LPD meningkatkan perekonomian masyarakat desa. Hal ini dapat dilihat bahwa komitmen afektif menjadi indikator yang memiliki nilai tinggi, yang berarti bahwa pegawai LPD memiliki rasa kepercayaan, rasa cinta kasih, dan rasa kepedulian yang sangat tinggi pada LPD tempat mereka bekerja yang dapat mendorong mereka dalam melakukan kinerja terbaiknya. Sedangkan indikator yang memiliki nilai rendah yaitu komitmen berkelanjutan yang berarti 
bahwa masih terdapat pegawai LPD tidak memiliki kemauan untuk keberhasilan dan kemajuan LPD.

Hasil penelitian ini juga didukung oleh penelitian-penelitian sebelumnya yang memaparkan terkait kecenderungan kecurangan (fraud) akuntansi bisa dipengaruhi oleh komitmen organisasi secara negatif dan signifikan (Widiautami ,2017);(Pratiwi (2019));(Virmayani (2017).

\section{Pengaruh Locus of Control Terhadap Kecenderungan Kecurangan (Fraud) Akuntansi}

Ditinjau dari hasil pengujian, locus of control berpengaruh positif dan signifikan terhadap kecenderungan kecurangan (fraud) akuntansi pada LPD di Kecamatan Seririt. Hal ini dapat dilihat dari hasil analisis regresi linier berganda yang membuat variabel locus of control (X2) berkoefisien positif 0,325 mengindikasikan timbulnya pengaruh positif diantara variabel locus of control (X2) pada variabel kecenderungan kecurangan (fraud) akuntansi (Y). Signifikansi uji t variabel locus of control (X2) bernilai 0,002 yang berada di bawah 0,05 berarti variabel kecenderungan kecurangan (fraud) akuntansi (Y) dipengaruhi oleh variabel locus of control (X2) secara signifikan. Regresi linier berganda yang dianalisis serta uji t mengindikasikan peningkatan locus of control (X2) seorang pegawai LPD mengakibatkan penurunan tingkat fraud. Sebaliknya, apabila seorang pegawai LPD memiliki tingkat locus of control (X2) yang rendah maka kecenderungan untuk melakukan fraud akan semakin meningkat. Jika locus of control cenderung ke eksternal, maka kecenderungan kecurangan (fraud) akuntansi semakin tinggi.

Pegawai LPD dengan locus of control internal yang tinggi lebih mengenali secara langsung hubungan antara perilaku dan hasil dari tindakannya. Akibatnya, seseorang dengan locus of control internal lebih bertanggung jawab dengan hasil dari tindakan atau perilakunya terhadap diri mereka sendiri dan menentukan sendiri mengenai apa yang benar dan salah untuk pedoman perilaku. Oleh karena itu, seseorang dengan locus of control internal cenderung memilih untuk terlibat dalam perilaku etis dan lebih tidak berpeluang melakukan tindakan kecurangan (fraud). Sebaliknya, seseorang dengan locus of control eksternal lebih bertanggung jawab dengan pihak-pihak lain dan faktor-faktor situasional, oleh karena itu mereka lebih berpeluang melakukan tindakan kecurangan (fraud).

Hasil penelitian ini juga didukung oleh penelitian-penelitian sebelumnya yang memaparkan terkait kecenderungan kecurangan (fraud) akuntansi bisa dipengaruhi oleh locus of control secara positif dan signifikan (Budiyanti ,2020);( Rahayu,2018);( Wirakusuma ,2019).

\section{Pengaruh Implementasi Good Governance Terhadap Kecenderungan Kecurangan (Fraud) Akuntansi}

Ditinjau dari hasil pengujian, implementasi good governance berpengaruh negatif dan signifikan terhadap kecenderungan kecurangan (fraud) akuntansi pada LPD di Kecamatan Seririt. Hal ini dapat dilihat dari hasil analisis regresi linier berganda yang membuat variabel implementasi good governance (X3) berkoefisien ne gatif -0,739 mengindikasikan timbulnya pengaruh negatif diantara variabel implementasi good governance (X3) pada variabel kecenderungan kecurangan (fraud) akuntansi (Y). Signifikansi uji t variabel komitmen organisasi (X1) bernilai 0,000 yang berada di bawah 0,05 berarti variabel kecenderungan kecurangan (fraud) akuntansi (Y) dipengaruhi oleh variabel implementasi good governance (X3) secara signifikan. Regresi linier berganda yang dianalisis serta uji t mengindikasikan peningkatan implementasi good governance (X3) dalam LPD mengakibatkan penurunan tingkat fraud. Sebaliknya, apabila LPD tidak mengimplementasikan prinsip good governance 


\section{Akuntansi pada Lembaga Perkreditan Desa di Kecamatan Seririt}

dengan baik pada LPD maka kecenderungan untuk melakukan fraud akan semakin meningkat.

Penerapan good governance dilakukan agar LPD dapat menjalankan praktik-praktik usaha secara sehat, terciptanya kegiatan yang transparan efektif dan efisien. Salah satu cara untuk meminimalisir kecurangan yaitu meningkatkan kultur organisasi yang dapat dilakukan dengan menerapkan prinsip-prinsip good governance (Tunggal, 2010). Melalui penerapan good governance secara optimal maka peluang munculnya tindakan kecurangan dapat ditekan sedini mungkin.

Hasil penelitian ini juga didukung oleh penelitian-penelitian sebelumnya yang memaparkan terkait kecenderungan kecurangan (fraud) akuntansi bisa dipengaruhi oleh implementasi good governance secara negatif dan signifikan (Ratnayani,2014); (Pratiwi,2019) dan Saftarini (2015).

\section{Simpulan dan Saran}

Berdasarkan hasil analisis dan pembahasan yang dilakukan, maka dapat ditarik simpulan bahwa komitmen organisasi berpengaruh negatif dan signifikan terhadap kecenderungan kecurangan (fraud) akuntansi pada LPD di Kecamatan Seririt. Hal ini dapat dilihat dari hasil uji t yang menyatakan nilai Sig. 0,007 lebih kecil dari 0,05 yang berarti h1 bisa diterima, locus of control berpengaruh positif dan signifikan terhadap kecenderungan kecurangan (fraud) akuntansi pada LPD di Kecamatan Seririt. Hal ini dapat dilihat dari hasil uji t yang menyatakan nilai Sig. 0,002 lebih kecil dari 0,05 yang berarti h2 bisa diterima, implementasi good governance berpengaruh negatif dan signifikan terhadap kecenderungan kecurangan (fraud) akuntansi pada LPD di Kecamatan Seririt. Hal ini dapat dilihat dari hasil uji t yang menyatakan nilai Sig. 0,000 lebih kecil dari 0,05 yang berarti h3 bisa diterima.

Adapun saran yang penulis berikan kepada pihak LPD yaitu melalui penelitian ini diharapkan lembaga perkreditan desa dapat meningkatkan komitmen organisasi khususnya komitmen yang bersifat berkelanjutan yaitu melalui pembagian wewenang sesuai keahliannya dengan memberikan kepercayaan terhadap pegawai dalam menjalankan tugasnya sehingga pegawai merasa lebih berperan dalam organisasi. Dengan dilakukan kegiatan pengarahan kepada karyawan secara rutin dan berkala sebelum memulai kegiatan operasional kerja, untuk menguatkan komitmen pegawai dalam bekerja. Hal ini diharapkan dapat meminimalisir kecenderungan kecurangan (fraud) akuntansi. Melalui penelitian ini diharapkan lembaga perkreditan desa dapat meningkatkan locus of control internal dari masing- masing pegawainya. Mengingat pentingnya locus of control dalam mempengaruhi kecenderungan kecurangan (fraud) akuntansi pada LPD di Kecamatan Seririt. Oleh karena itu, perlu adanya tindakan untuk membangun locus of control internal yang tinggi pada karyawan melalui pembinaan dan pelatihan terkait internalisasi nilai-nilai yang berhubungan dengan kepercayaann dan motivasi diri. Selain itu, pengendalian terhadap locus of control eksternal pegawai LPD juga penting untuk dilakukan melalui dukungan lingkungan kerja yang positif dan menerapkankan prinsip reward \& punishment guna membangun budaya kerja yang baik sehingga terhindar dari tindakan penyelewengan. Dan melalui penelitian ini diharapkan lembaga perkreditan desa dapat meningkatkan implementasi good governance, khususnya pada pengimplementasian prinsip transparansi. Oleh karena itu, perlu adanya tindakan untuk meningkatkan transparansi dalam LPD melalui meningkatkan kualitas pelayanan kepada masyarakat, melakukan pembinaan dan pelatihan kepada pengurus LPD, meningkatkan keterbukaan informasi laporan keuangan kemasyarakat. Hasil penelitian menunjukkan koefisien determinasi sebesar 0,736, artinya variabel kecenderungan kecurangan (fraud) akuntansi dipengaruhi oleh variabel komitmen organisasi, locus of 
control, dan implementasi good governance sebesar 73,6\%, sedangkan sisanya $26,4 \%$ dipengaruhi oleh faktor lain.

Oleh karena masih terdapat faktor lain yang mempengaruhi kecenderungan kecurangan (fraud) akuntansi, maka bagi peneliti selanjutnya disarankan agar menambahkan variabel bebas lain yang dapat mempengaruhi kecenderungan kecurangan (fraud) akuntansi. Disarankan untuk peneliti selanjutnya untuk menambah populasi penelitian, yaitu dengan menambah jumlah Lembaga Perkreditan Desa tidak hanya yang berada di Kecamatan Seririt saja, sehingga diperoleh hasil penelitian yang tingkat generalisasinya lebih tinggi. Disarankan agar peneliti selanjutnya tidak hanya menggunakan metode pengumpulan data dengan kuesioner saja, tetapi juga dengan menggunakan metode pengumpulan data melalui wawancara sehingga informasi yang diperoleh lebih lengkap dan akurat..

\section{Daftar Pustaka}

Adinda, Yanita Maya. 2015. Faktor Yang Mempengaruhi Terjadinya Kecurangan (Fraud) Di Sektor Pemerintahan Kabupaten Klaten. Accounting Analysis Journal. Universitas Negeri Semarang, 4 (3), Hal. 7-9.

Badewin, B. 2018. Pengaruh Efektivitas Pengendalian Internal, Asimetri Informasi dan Implementasi Good Governance Terhadap Kecenderungan Kecurangan Akuntansi Pada SKPD Kab. Indragiri Hilir. Jurnal Akuntansi Dan Keuangan, Vol.7 No.1. ISSN : 2089-6255.

Budiyanti, Putu Mita. 2020. "Pengaruh implementasi good governance Dan locus of control terhadap Kecenderungan kecurangan(Fraud) Akuntansi dengan perilaku tidak etis Sebagai variabel intervening (Studi Empiris pada LPD di Kecamatan Buleleng)" Skripsi. Fakultas Ekonomi dan Bisnis Universitas Pendidikan Ganesha.

Ghozali, Imam. 2011. Aplikasi Analisis Multivariate dengan Program IBM SPSS 19. Edisi 5. Semarang: Badan Penerbit Universitas Diponegoro.

Ikhsan, Arfan. 2011. Akuntansi Keperilakuan. Edisi Dua. Jakarta: Salemba Empat

Karyono.2013.Forensic fraud. Edisi I.Yogjakarta.ANDI.

Kurniawan, Moh Rizki Nur. 2011. "Pengaruh Komitmen Organisasi, Budaya Organisasi dan Kepuasan Kerja terhadap Kinerja Organisasi Publik”. Demak. FE Universitas Diponegoro.

Lestari, Ayu Puji. 2010. Faktor-faktor yang mempengaruhi perilaku auditor dalam penghentian prosedur audit: studi empiris pada kantor akuntan publik.Skripsi.Univeristas Diponegoro Semarang.

Mustofa.2020.“Terungkap Indikasi Penyelewengan Dana LPD Unggahan”. Dalamhttps://www.nusabali.com/berita/66226/terungkapindikasipenyelewengan-dana lpd-unggahan. Diakses pada 01 Januari 2021.

Peraturan Daerah No.2/1998 Dan No.8/Tahun 2002 Tujuan Pendirian Sebuah LPD Pada Setiap Desa Adat.

Pratiwi, Putu Ririn. 2019. "Pengaruh Pengendalian Internal, Komitmen Organisasi, Dan Implementasi Good Governance Terhadap Kecendrungan Terjadinya Kecurangan 
Pengaruh Komitmen Organisasi, Locus Of Control dan Implementasi Good Governance terhadap Kecenderungan Kecurangan (Fraud) Akuntansi pada Lembaga Perkreditan Desa di Kecamatan Seririt

(Fraud) (Pada Lembaga Perkreditan Desa Se-Kecamatan Pupuan, Kabupaten Tabanan)".Skripsi. Fakultas Ekonomi dan Bisnis Universitas Pendidikan Ganesha.

Rahayu, Ananti Putri. 2020. Pengaruh Pengendalian Internal, Sistem Informasi Akuntansi Dan Komitmen Organisasi Terhadap Pencegahan Kecurangan Akuntansi. Skripsi. Univeristas Negeri Jakarta.

Saftarini, R., Yuniarta, G. A., \& Sinarwati, N. K. 2015. Pengaruh Efektivitas Pengendalian Internal, Asimetri Informasi Dan Implementasi Good Governance Terhadap Kecenderungan Kecurangan (fraud) Akuntansi (Studi Empiris pada SKPD di Kabupaten Bangli), 3 (1). Jurusan Akuntansi Program S1 Fakultas Ekonomi Universitas Pendidikan Ganesha..

Sari,Ni Luh Putu Purnama, dkk. 2015. Pengaruh Efektifitas Sistem Pengendalian Internal, KetaatanAturanAkuntansi, Persepsi Kesesuaian Kompensasi dan Implementasi Good Governance Terhadap Kecenderungan fraud (Studi Empiris Pada SKPD di Kabupaten Tabanan). Jurnal Akuntansi Program S1(Volume3,No.1).

Suarniti, Ni Luh Putu Eka \& Maria Mediatrix Ratna Sari. 2019. Pengaruh Moralitas Individu, Komitmen Organisasi dan Kesesuaian Kompensasi pada Kecurangan Akuntansi di LPD se-Kecamatan Mengwi. Vol. 30 No. 2. e-Jurnal Akuntansi. e-ISSN 2302-8556

Suyatra. 2019. "Gunakan Uang Nasabah Rp. 160 Juta, Ketua LPD Pengastulan Dipolisikan".Dalamhttps://baliexpress.jawapos.com/read/2019/08/23/152253/gunakan -uangnasabah-rp-160-juta-ketua-lpd-pengastulan-dipolisikan. Diakses pada 01 Januari 2021.

Tunggal, A. W. 2010. Dasar-dasar audit intern pedoman untuk auditor baru. Jakarta:Harvarindo.

Virmayani, Putu Crysma, Ni Luh Gede Erni Sulindawati, dan Anantawikrama Tungga Atmadja. 2017. "Pengaruh Kesesuaian Kompensasi, Asimetri Informasi, Budaya Etis Organisasi dan Komitmen Organisasi Terhadap Kecenderungan Kecurangan (Fraud) Akuntansi Pada Koperasi Simpan Pinjam Se-Kecamatan Buleleng”. E-Journal S1 Akuntansi Universitas Pendidikan Ganesha, Vol. 7, No. 1.

Widiutami, Ni Putu Sri. 2017. Pengaruh Efektivitas Pengendalian Internal, Ketaatan Aturan Akuntansi, Dan Komitmen Organisasi Terhadap Kecenderungan Kecurangan (Fraud) Akuntansi (Studi Empiris Pada Lembaga Perkreditan Desa di Kabupaten Buleleng). $e$ Journal S1 Ak (Vol: 7 No: 21). Jurusan Akuntansi Program S1 Universitas Pendidikan Ganesha.

Wirakusuma, I. G. B., \& Setiawan, P. E. 2019. Pengaruh Pengendalian Internal, Kompetensi dan Locus Of Control Pada Kecenderungan Kecurangan Akuntansi Dinas Pendapatan Daerah Kota Denpasar. E-Jurnal Akuntansi, 1545-1569. ISSN: 2302-8556

Zakky. 2020. “Korupsi Rp 355 Juta, Ketua LPD Kalianget Jadi Tersangka”.Dalam https://www.nusabali.com/berita/87282/korupsi-rp-355-juta-lpd-kalianget-jaditersangka Diakses pada 01 Januari 2021. 